\title{
Students Learning Experience in the Integrated Information Literacy Course Constructed in Virtual Learning Environment
}

\author{
Vilhelmina VAIČIŪNIENĖ \\ Department of Foreign Languages, Mykolas Romeris University, Vilnius \\ Ateities 20á, 08303 Vilnius, Lithuania \\ e-mail:vvaiciun@mruni.lt
}

Genutė GEDVILIENE

Department of Social Sciences, Vytautas Magnus University

Donelaičio 52, 44248 Kaunas, Lithuania

e-mail: g.gedviliene@smf.vdu.lt

Received: October 2007

\begin{abstract}
The paper examines the impact of ICT on students learning experiences and opportunities offered by virtual learning environment as an integral part of traditional learning environment in the experimental course "Integration of information literacy skills into ESP programme" at Mykolas Romeris University (Lithuania). The experiment aimed at developing students' information literacy and social skills as the means for enhancement of learning with a particular attention towards foreign language competencies. The integrated information literacy course into ESP (English for specific purposes) syllabus addressed students' needs of information literacy skills striving for better performance and efficiency in academic studies. The focal points of the research presented in the paper are: a) students' attitudes towards the learning environment offered by software Moodle; b) information literacy knowledge and skills developed within and with the assistance of Moodle; c) enhancement of social communication and collaboration; d) the impact of information literacy course on ESP competencies in a complex learning environment.
\end{abstract}

Keywords: information literacy, constructivism in learning, virtual learning environment, social interaction, ICT competencies, ESP.

\section{Introduction}

Education in Lithuania is undergoing great transformations that are affecting all types of education: formal, non-formal, and informal. The debate among Lithuanian scholars rests on shift in education paradigm that is proceeding in line with great transformations in other areas of the state due to the membership in the EU (May, 2004) and participation in international forums and organizations. Today's education at large experiences challenges caused by new technologies, abundance of information sources, thus being forced to search for new and effective methods of teaching/learning with the application of sophisticated technologies and tools. 
In the Long-Term Development Strategy of Lithuania three priority areas: knowledge society, secure society and competitive economy were identified (Parliament of LR, 2002). The document envisages Lithuania as a country building a civil society with a knowledge-based economy where Euro-Atlantic values are appreciated. European and national documents on education (Report of the Committee by the Government of LR, 2003; Strategy of ICT in Education, 2000; Lisbon Special European Council, 2000) emphasize the development of human potential and necessary competencies to apply modern ICT. Despite the fact that the terms computer literacy, ICT literacy, IT competency are frequently met in Lithuanian documents on education (Students' General Computer Literacy Standard, 2001; Teachers' Computer Literacy Standard, 2001; Computer Literacy Standards for School Librarians, 2002; General computer Literacy Standard, 2004) the issue of information literacy has not been researched in more depth. Flexible and universal application of information technologies in teaching/learning is emphasized with the view to new educational aims related to modern education methods and individual learners' needs in Strategy of Integration of ICT in Education of Lithuania (2000). The documents on computer literacy adopted by the Ministry of Education and Science define the level of qualifications to deal with computer equipment and software, their application for learning purposes. However, they lack deeper analysis of skills development necessary for efficient application of technologies in learning. Therefore, higher education is facing a challenging responsibility to educate a highly competent professional, able to act efficiently and effectively.

The paper presents descriptive analysis of EU and Lithuanian documents and research literature on education and learning. The study explores the impact of ICT on students' learning experiences and opportunities offered by using virtual learning environment as an integral part of traditional learning environment. The major aims of the study are: a) students' attitudes towards the learning environment offered by software Moodle; b) information literacy knowledge and skills developed within and with the assistance of Moodle; c) enhancement of social communication and collaboration; d) the impact of information literacy course on ESP competencies in a complex learning environment.

\section{Constructivism in Learning}

Constructivism has been in the focus of education science theorists and practitioners for the last several decades. Constructivism is involved in thinking about the nature of human learning and the conditions that best promote the varied dimensions of human learning transformations. Educational psychologists (Vygotsky, 1978; Applefield and Huber, 2001) in their theories based on the educational philosopher John Dewey consider that construction of knowledge happens in a social context. Scholars interested in learning innovation suggest that knowledge and learning activities should be presented in authentic context with social interaction and collaboration.

The constructivist learning environment is especially favorable for online learning or learning practice with the use of ICT. Such learning model allows arranging studentcentered activities, problem-based activities, enhances creativity, interaction, reflection, 
and collaboration. A constructivist learner uses creative approach to apply their own meaning to the topic using social and cognitive circumstances, share ideas, problems and concerns. Collaborative learning or collaborative group work are characteristic features of knowledge construction. Vygotsky (1978) suggested that learners are capable of performing at higher intellectual levels when they are asked to work in group situations rather than when they work individually.

Scientific discourse on constructivism is gaining greater attention among Lithuanian scholars. Constructivist learning strategies of cooperative learning, activities and experiences of teams involving social interaction have been researched by Teresevicienè and Gedvilienè (2003). A research into learning in groups in high schools carried out in 19941995 revealed that such learning oriented students to more intensive learning, changed their social skills, making learners interact, listen and understand others.

\section{Information Literacy}

Today's information society transcends all political, social, and economic boundaries. In modern learning environment with an abundance of information resources and formats information literacy skills become crucial. Information literacy is defined as "a set of abilities requiring individuals to recognize when information is needed and have the ability to locate, evaluate, and use effectively the needed information" (ALA, 1998). The term of information literacy and its interpretations are within the present researchers' interest domain. There are certain elements that link definitions of information literacy:

- understanding the information need,

- information search,

- its use,

- evaluation,

- application for personal needs,

- communication.

Very often the term is identified as computer or IT literacy, electronic, media, net, hyper or internet, digital literacy or even "informacy". Skill-based literacies (computer, IT, electronic, etc.) characterize abilities for a particular area, for example, to work with a computer or search information in a library. Conversely, information literacy defines much more general abilities such as self-directed learning, abilities to utilize a variety of information resources and formats, have deep understanding and knowledge of the information world, and internalize values that motivate ethical and legal use of information. Information literacy conception incorporates other literacies necessary to function efficiently in the modern society. Some authors argue that different ideas of information literacy and often too narrow interpretation of the concept encourages students' surface approach to learning, for example, understanding information literacy as library instruction. Thus, information literacy being a more general concept, embraces more specific literacies of a particular area. The significance of the term is associated with complexity of information environment, information products, digital space (Bawden and Robinson, 2002; Behrens, 1994). 
Information literacy skills are considered to be generic in education and form background for lifelong learning (ANZIL, 2004). Scholars working on information literacy in USA, Australia, and UK relate information literacy skills with developing critical thinking and reflective practice. " $<\ldots>$ advanced information literacy needs to be addressed by learning and teaching strategy which incorporates evaluation, comparison, reflection and exchange of views" (Johnston and Webber, 2000, p. 341). Johnston and Webber (2000) defining the concept of information literacy emphasize the importance of dialogue and critical thinking. In modern technology-rich learning environment active participation is hardly possible without possessing good, if not excellent information literacy skills, considering the development of persons' competencies to use modern IT and information resources as one of the key objectives in the formation of information society. The term key competencies were researched in Gedvilienè and Vaičiūnienè (2005). EC expert group defined them as "a hybrid attribute involving a combination of knowledge, skills and competence attitudes" whereas skills are defined as an "ability to do" (EC, 2004, p. 20). "Key competencies represent a transferable, multifunctional package of knowledge, skills and attitudes which individuals need for personal fulfilment/development, inclusion and employment which should have developed by the end of compulsory school or training, and act as a foundation for Lifelong Learning" says the definition worked out by the expert group. Development of information literacy competencies creates opportunities for independent learning where students engage in using a wide variety of information sources to expand and construct their knowledge, ask informed questions, and sharpen their critical thinking.

\section{Learning Environment}

The concept of a learning environment has been researched since the first part of the 20th century. Chang and Fisher $(1998,2003)$ emphasize students' perceptions in learning environment as extremely important for researchers exploiting the issue. Research into learners' attitudes and perceptions of various environments deepens understanding of a learning phenomenon. In Lithuania the learning environment has been researched extensively by Tautkevičienè $(2002,2004)$ who investigated learning environment at university level. Jucevičienè and Tautkevičienè (2004) differentiated educational and learning environments: educational is understood as multidimensional environment, whereas learning environment is conceived as an individual-level dimension. The best effect from the view of a learning process and its outcomes can be achieved when educational environment fully corresponds to the learning environment of individual/s.

Phenomenographic researchers who focus on learning and learners experiences see learning "as a change in the learner's capability of experiencing a phenomenon in the world around them" (Marton and Fai, 1999). They claim that perceptions of learning environment phenomena and content of learning are highly important for understanding how learning occurs. Learning is closely linked to a specific learning content. Limberg (1997) who investigated information seeking and learning phenomenon reasons that knowledge 
implies a qualitative aspect, i.e., to "become more knowledgeable in a subject implies qualitative change to a deeper and more complex understanding of a phenomenon".

Similarly Berglund (2004) explored phenomenographic approach for research of students' experiences in complex computer-supported environment. He argues that learning outcomes are closely related to the experience of learning environment. Therefore, analysis of such experiences can provide with clues how learning environment and learning itself could be improved.

The use of ICT in education is a modern challenge forcing to rethink a number of educational issues. Loveless (2002) highlights a set of favorable features of the use of ICT in learning: collaboration, student's autonomy, being original, being critical, imaginative expression. Jones (2004) argues that today's discussion is transferred from the interaction with computers to interaction through computers, thus indirectly implying interaction with information that networks can offer. The author discusses the issues of networked society and the context of networked learning: "The computer itself is no longer the centre of research attention; instead it is the network and network resources made available through the computer" $(2004$, p. 89$)$. Theoretical insight into the ways ICT enhance learning encourages applying new technologies in learning more frequently and for the good of students.

\section{Moodle Software Package}

The software package Moodle (originally acronym of Martin's Object-Oriented Dynamic Learning Environment) today is known as Modular Object-Oriented Dynamic Learning Environment. It has been developed by Martin Dougiamas, a former WebCT administrator at Curtin University of Technology (Australia). The software programme was designed to support a social constructionist epistemology of teaching and learning within Internet-based communities of reflective inquiry (Dougiamas, 1998; Dougiamas and Taylor, 2003). Moodle working since 1999 is a modular framework allows creating new activity modules; supplement them with new assignments according to students needs and/or teachers projected aims. Moodle incorporated the philosophy of constructivist learning theory with its social features, engaging students into collaborative and cooperative work. Thus, by bringing learners together through group discussion, news forums it stimulates students' social competencies. On the other hand, it is a highly valuable tool for enhancement of students' language competencies.

Dougiamas highlighted two distinct learning styles: separate knowing and connected knowing and put stress on connected knowing in learning process. On the assumption that knowledge is constructed in a learner's mind, not transmitted Moodle provides an opportunity to create learning environment favorable for student-centered learning, collaborative learning. Understanding is facilitated by exchanges that occur through social interaction, questioning and explaining, challenging and offering timely support and feedback. Learning communities focus on helping group members learn, by supporting one another through respectful listening and encouragement. 


\section{Methods}

The integrated information literacy course into ESP (English for specific purposes) programme at Mykolas Romeris University (Lithuania) addresses the students' needs for information skills seeking better performance and efficiency in academic studies. The experimental course "Integration of information literacy skills into ESP programme" for the 1st year students of Law and Customs Activities bachelor programme of studies was started in autumn, 2005. Two groups took part in the longitudinal experiment: experimental group (17 students) and control group (15 students). The research sample at the beginning of the experimental course was thirty two students. In the second term of the academic year 2005/2006 one student from the experimental group dropped out. The experimental treatment (using virtual learning) was applied to one of the groups; whereas the control group had a traditional course of ESP according to the approved ESP syllabus.

The focal point of the experiment was development of academic competencies within a framework of the learning community. The novelty of the course lied in the idea to integrate information literacy into ESP classes. The course was designed to link traditional teaching/learning method based on a course book on ESP with information literacy knowledge and skills development, thus constructing the so called blended learning. It was tailor-made to address such information literacy issues as:

- effective search and evaluation of web-based resources of information;

- copyright and plagiarism issue;

- narrowing/broadening techniques of a theme;

- application of ICT for specific, profession-context tasks.

The experiment aimed at developing students' information literacy knowledge and skills as the means of facilitating ESP competencies. ESP learning/teaching implies an interdisciplinary aspect involving intercultural studies. Hence, students' skills to evaluate information resources, web-based included, critical thinking, problem solving become of key importance. Information literacy course was focused on the skills that addressed ESP teaching aims and assignments.

The experimental course aimed to fulfil multifold objectives:

- development of information literacy skills;

- development of language competencies;

- fostering collaborative/social skills;

- enhancement of ICT skills;

- deepening students understanding of learning process as a reflective practice.

Striving to conform to the aims and objectives of the course the software Moodle was explored. The components of Moodle learning environment explored in the experimental course are presented in Fig. 1.

Moodle was administered with the assistance of IT specialist form the Distance Studies Center of the university and applied accordingly to the course requirements id est. carrying out research, making presentations, open group discussions on current events, written assignments on subject - related topics, writing a reflective diary. Moodle is a user-friendly environment for students' communication and collaboration. At the beginning of the experimental course students' attitude towards communication within Moodle 


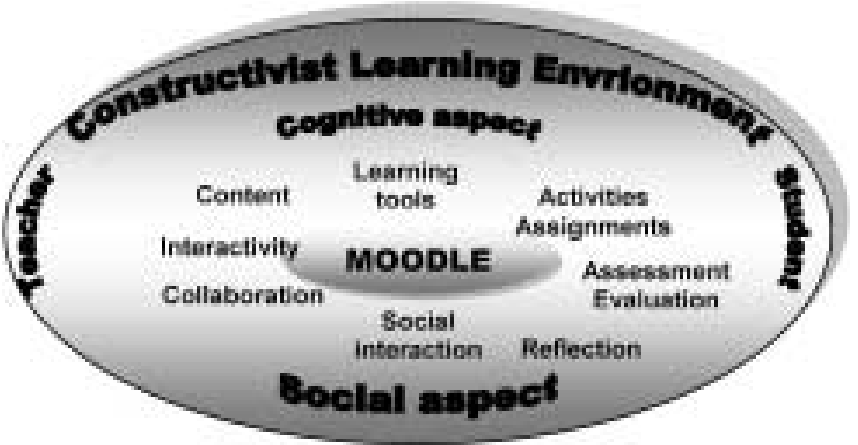

Fig. 1. Components of Moodle learning environment.

was rather reserved, but in the course their communication with the teacher and peers was progressing in a more open and friendly manner.

Typically students have two classes (4 academic hours) a week. Once a week the experimental group had an ESP class in a computer equipped classroom where they worked within Moodle learning environment to cover information literacy topics, develop their IT and information literacy skills and apply them practically dealing with a chosen ESP topic/assignment. The experimental course took a lot of students' out-of-classroom time as they were asked to fulfill longtime assignments, communicate on-line, search for pedagogically unprocessed information and apply it for the given task. Students were encouraged to reflect and rethink learning process by writing a reflective diary visible to peers and teachers.

The intermediary and final results of the research were accumulated via: a) quantitative analysis of the collected data using Statistical Package for the Social Sciences (SPSS) version 12.0 for Windows; b) qualitative analysis of the data by administering a questionnaire on their attitudes towards Moodle learning environment and social interaction; the data received by interviewing participants of the experiment. The findings revealed the ways in which technology facilitated the development of students' information literacy skills, social interaction and communication by building a learning community.

\section{Discussion of the Results}

\subsection{Students Conception of Information Literacy Phenomenon}

Prior to the experiment a structural procedure aiming at interviewing the respondents' on their awareness of and attitude to information literacy phenomenon had been applied. The interviewees were the first year students whose secondary school experience concerning information literacy was investigated. An open-ended questionnaire composed of three questions was administered to both groups: a) Have you ever heard the information literacy concept? In what context? b) How would you interpret information literacy concept? c) Would it be useful to know more about information literacy? Present your comments. 
The findings revealed controversial understanding and very often misconception of information literacy phenomenon. The majority of the students (30) encountered the term prior to university studies. More than a half of the participants (17) perceived information literacy as a competency to deal with a computer and its programs, or competency to apply IT. Two students presented rather comprehensive explanation of information literacy conception. The rest of the interviewed students related the concept with the Internet, computer-aided typing or writing. The majority of the respondents (29) expressed the need to gain theoretical knowledge on information literacy together with practical skills as being useful for their future career. Phenomenographic research into understanding information literacy provided with insights into students' idea of information literacy perspective as the necessity of future society with domination of ICT in all spheres of life. However, this study highlighted students' information literacy understanding limited to IT literacy necessary for information search and communication. Such interpretation can become a serious obstruction to students' enhancement of deep-learning approach, thus reducing the quality of learning and studies in general. The obtained findings validated the necessity of information literacy integration into the academic subject programme (ESP).

\subsection{Information Literacy Test Results}

During the experimental treatment the experimental group was acquainted with the information literacy concept and skills to be acquired in order to be information literate. Information literacy test was applied twice during the course and the mean scores were compared. The test was based on the interactive teaching material and online test TILT which was used in the experimental course. The test was composed of four parts each comprising 10 questions: Part 1 - General knowledge on information literacy which covered theoretical knowledge on information literacy (copyright issue, netiquette, etc.); Part 2 - Selecting was related to information search locations and evaluation information resources (library versus web resources, data bases); Part 3 - Searching related to information searching strategies (key words, Boolean operators); Part 4 - Evaluation related to information evaluation techniques with a special focus on web-based information, plagiarism issue. The test designed by the experimenter was also presented in an online version within Moodle, therefore students could instantly see their results. The first test was administered by the end of the experiment and the second testing took place after two months period. The mean of the first test was 8.20 and the performance during the second test was very similar (see Table 1).

Table 1

Means on information literacy tests

\begin{tabular}{ccccc}
\hline Information literacy test & Mean & $\mathbf{N}$ & Std Deviation & Std Error Mean \\
\hline 1 & 8.2031 & 16 &, 7704 &, 1926 \\
2 & 8.2188 & 16 &, 4905 &, 1226 \\
\hline
\end{tabular}


The obtained data indicated no difference between the scores of test 1 and test 2 ( $Z$ statistics $p$-value $=0.95, p>\alpha$, when $\alpha=0.05$ ), thus indicating good knowledge on information literacy acquired during the experiment.

\subsection{Student Attitudes to Moodle Learning Environment}

Student attitudes towards virtual learning environment offered by Moodle and its impact on development of their competencies and skills was investigated by administering a questionnaire composed of 11 variables to the experimental group participants. The applied Kendall's $\tau-b$ correlation coefficient $(r)$ indicated relational interaction between the variables.

The most significant interaction was observed between Moodle learning environment $(A)$ and information literacy competencies $(C)$. Development of information literacy skills depends greatly on friendly and encouraging learning environment $(r=0.619)$. Critical thinking skills $(I)$ learners acquire through active participation within Moodle friendly and encouraging environment $(r=0.500)$. Moodle flexible learning environment allows accessing and utilizing it at students' convenience $(K)$. The respondents expressed opinion that convenience to use this environment developed skills vital for their studies and future career $(J)(r=0.568)$.

The other correlations were not so strong: Moodle supports learning $(B)$ and enhancement of ESP competencies $(D)(r=0.428)$; Moodle supports leaning $(B)$ and encourages self-reflection $(H)(r=0.408)$; friendly and encouraging Moodle environment $(A)$ develops skills for future career $(J)(r=0.444)$. Development of skills for future career $(J)$ correlates with promotion of critical thinking skills $(I)(r=0.476)$. The findings that are presented in Table 2 revealed students' positive attitude to Moodle software. The investigated parameters presented in the table are coded by letters indicated below.

\subsection{Social Communication and Collaboration}

Student attitudes to social interaction in learning were researched via the questionnaire applied to both groups: experimental and control. The internal validity of the scale was tested by Cronbach alpha - 0.847. ANOVA procedure was applied for comparison of the mean scores. The comparative analysis of the mean scores between two groups highlighted some differences. However, statistically significant difference was not observed. The most significant difference was observed concerning students' responses on preference of working alone $(D)$ : the control group $(c)$ participants tended more to work individually compared to the experimental group $(e)$ students $(c-3.46 ; e-3.00)$. For the variable $(K)$ - "group work encourages me to think critically and reflectively" the following results were obtained: $e-2.20, c-1.75$. This finding points to the fact that control group students learning experience did not encourage them to think critically and reflectively. Although the control group students claimed that "communication expands learning" (variable $A$ ) $e-1.56 ; c-1.80$, the experimental group students seemed to be more inclined to share their knowledge with the group mates (variable $E)(e-2.49 ; c$ 
Table 2

Student attitudes to Moodle virtual learning environment

\begin{tabular}{rrrrrrrrrrrrr}
\hline & $A$ & $B$ & $C$ & $D$ & $E$ & $F$ & $G$ & $H$ & $I$ & $J$ & $K$ \\
\hline$A$ & 1.000 & 0.139 & $0.619^{\prime \prime}$ & 0.361 & 0.220 & 0.379 & 0.135 & 0.073 & $0.500^{*}$ & 0.444 & 0.361 \\
$B$ & 0.139 & 1.000 & -0.075 & 0.428 & 0.294 & 0.077 & 0.192 & 0.408 & -0.174 & -0.013 & -0.013 \\
$C$ & $0.619^{\prime \prime}$ & -0.075 & 1.000 & -0.110 & 0.317 & 0.197 & 0.286 & -0.055 & 0.385 & 0.374 & 0.378 \\
$D$ & 0.361 & 0.428 & -0.110 & 1.000 & 0.103 & 0.389 & -0.011 & 0.286 & -0.052 & -0.118 & -0.058 \\
$E$ & 0.220 & 0.294 & 0.317 & 0.103 & 1.000 & 0.236 & 0.282 & 0.124 & 0.217 & 0.396 & 0.251 \\
$F$ & 0.379 & 0.077 & 0.197 & 0.389 & 0.236 & 1.000 & 0.068 & 0.034 & -0.013 & 0.430 & 0.343 \\
$G$ & 0.135 & 0.192 & 0.286 & -0.110 & 0.282 & 0.068 & 1.000 & -0.068 & 0.154 & 0.257 & 0.115 \\
$H$ & 0.073 & 0.408 & -0.055 & 0.286 & 0.124 & 0.034 & -0.068 & 1.000 & -0.051 & 0.081 & 0.183 \\
$I$ & $0.500^{*}$ & -0.174 & 0.385 & -0.520 & 0.217 & -0.013 & 0.154 & -0.051 & 1.000 & 0.476 & 0.039 \\
$J$ & 0.444 & -0.013 & 0.374 & -0.118 & 0.396 & 0.430 & 0.257 & 0.081 & 0.476 & 1.000 & $0.568^{*}$ \\
$K$ & 0.361 & -0.013 & 0.378 & -0.058 & 0.251 & 0.343 & 0.115 & 0.183 & 0.039 & $0.568^{*}$ & 1.000 \\
\hline
\end{tabular}

Descriptives:

$\begin{array}{ll}A \text { - friendly and encouraging, } & B \text { - supports learning, } \\ C \text { - develops IL competencies, } & D \text { - enhances ESP competencies, } \\ E \text { - opportunities for interaction, } & F-\text { stimulates creativity, } \\ G \text { - develops IT skills, } & H \text { - encourages self-reflection, } \\ I \text { - promotes critical thinking, } & J-\text { develops skills for future career, } \\ K \text { - convenience to use. } & \end{array}$

- 2.00). A distinct difference was obtained related on the variable "enjoyment of working in group" (variable $C$ ): the mean score for the experimental group was 2.18 and the control group -1.93 . The experimental group participants revealed their active participation in group discussion (variable $I$ ) -2.68 , whereas the control group was more passive (2.40). Variable $F$ and $G$ showed that part of the students suggested that their achievements were higher when they work in group (variable $F$ ) and part of them when they work individually (variable $G$ ). The obtained results on the variable $\mathrm{H}$ demonstrated that the experimental group students were more responsive to their peers $(e-2.37 ; c-$ 2.13). Both groups presented similar opinion concerning the variable $J$ "communication enhances ESP competencies" $(e-2,06 c-2,00)$.

The findings can be interpreted as the positive impact of the so called blended learning (traditional classroom setting mixed with virtual learning tools) applied in the experimental course. The experimental group students were encouraged to communicate online in group or pair discussions on professional and up-to-date topics, share their knowledge, opinions, study results. Moodle platform created favourable conditions for both synchronous and asynchronous communication, as students had access to Moodle from their PC being out of the classroom or university environment, whereas the control group students' communication was most probably limited to classroom time. The research findings imply that social communication and collaboration skills can be best revealed if students are encouraged and trained to apply them in practice. The findings are presented in Fig. 2; investigated variables coded by letters are indicated below the figure. 


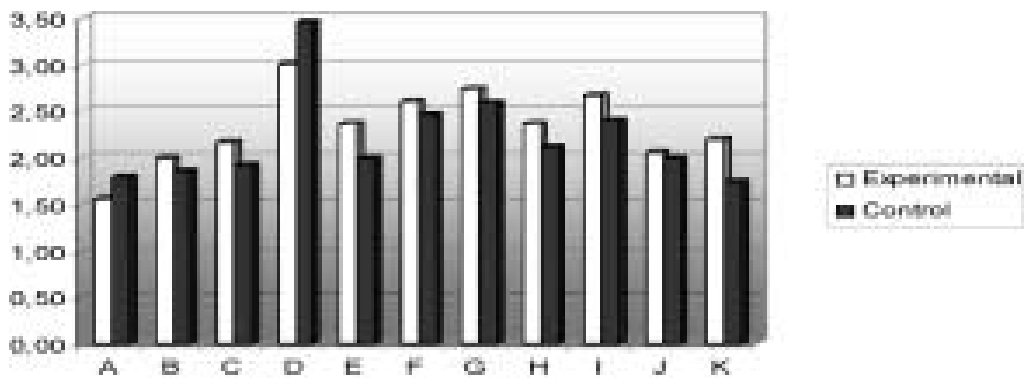

Descriptives:
$A$ - communication expands knowledge,
$B$ - importance of collaboration learning,
$C$ - enjoyment of group work,
$E$ - share knowledge,
$D$ - prefer working alone,
$G$ - achieve better results individually,
$F$ - achieve better results in group,
$I$ - participate in group discussion,
$H$ - respond to peers opinion,
$K$ - group work encourages reflective thinking.
$J$ - communication enhances ESP competencies,

Fig. 2. Comparison of students' attitudes to collaboration and social communication.

\subsection{Comparison of Students' Achievement in the Experimental and Control Groups}

Both groups' achievements in writing ESP vocabulary tests have been compared and processed data are presented in Table 3. At the beginning of the academic year a diagnostic test on general English was administered to both groups. The experimental group average score amounted to $68 \%$, whereas control group performed slightly better $-70 \%$. During the autumn period, 2005 period students performed two vocabulary tests on professionrelated topics. The average mark from two tests in 10-point scale was $7.6(76 \%)$ for the experimental group and 6.7 (67\%) for the control group (see Table 3).

By the end of the experiment the mean score for both groups was calculated and the final test marks were compared between the groups. The mean score of the final test was significantly higher in the experimental group (8.48) compared to the mean score -7.87

Table 3

Comparison of ESP tests scores

\begin{tabular}{|c|c|c|}
\hline \multicolumn{3}{|c|}{ Tests Scores } \\
\hline & Experimental group (\%) & Control group (\%) \\
\hline Diagnostic test & 68 & 70 \\
\hline \multicolumn{3}{|c|}{ Performance tests (10 - point scale) } \\
\hline Performance test 1 & 6.8 & 5.3 \\
\hline Performance test 2 & 8.3 & 8.2 \\
\hline Total & 7.6 & 6.7 \\
\hline$\%$ & 76 & 67 \\
\hline
\end{tabular}


of the control group. For the reason of convenience the mean scores have been rounded up to two figures after the comma (see Table 4).

In respect that the research samples were small the Student's distribution was used. The experimental impact on students ESP achievement was investigated by applying paired $t$ test within both groups. Comparative analysis revealed that both groups performed better at the end of the experiment. In the experimental group a very high level of significance was obtained $d f-15, t-7.211, p$-value $=0.0001$ the difference was absolute. The comparison of the diagnostic and final test mean scores of control group students showed also a statistically significant difference $-d f-14, t-4.108, p$-value $=$ 0.001 .

The independent samples test was used for the comparison of the data between the groups, which is typically applied for the comparison of the mean of the variable between two independent samples. The final test scores between the experimental and control groups highlighted significance of difference at $d f-29, t-2.706, p$-value $=0.01$. This indicates that the difference is essential, justifying the positive impact of the experimental treatment of information literacy course applied in the experimental group (see Table 5).

The level of statistical significance found after processing the data has shown students progress of English for professional purposes, thus indicating a favourable impact of the experimental course on their ESP knowledge and skills.

Table 4

Group statistics

\begin{tabular}{llccc}
\hline Test & Group & N & Mean & Std Deviation \\
\hline \multirow{2}{*}{ Diagnostic } & Experimental & 16 & 6.75 &, 7607 \\
& Control & 15 & 7.00 &, 6633 \\
\hline \multirow{2}{*}{ Final } & Experimental & 16 & 8.48 &, 5636 \\
& Control & 15 & 7.87 &, 6850 \\
\hline
\end{tabular}

Table 5

Independent samples test

\begin{tabular}{cccccc}
\hline Final test & \multicolumn{2}{c}{$\begin{array}{c}\text { Levene's Test for Equality } \\
\text { of variances }\end{array}$} & \multicolumn{1}{c}{ t-test for Equality of Means } \\
\cline { 2 - 5 } & Sig & $t$ & $d f$ & $p$-value \\
\hline 619 &, 438 & 2.706 & 29 & 0.010 \\
\hline
\end{tabular}




\section{Conclusions}

The research findings into the experimental course "Integration of information literacy skills into ESP programme" indicated the positive impact of virtual learning environment on students' learning outcomes. The findings on student attitudes towards Moodle virtual learning environment revealed that it supports learning, develops information literacy skills, promotes critical thinking skills, IT skills, encourages self-reflection, and enhances ESP competencies.

Comparative analysis of the data on students' attitude to social interaction in learning did not present statistically significant difference. However, the obtained results indicated differences between the groups. The experimental group students experienced enjoyment of working in group and claimed that such activity encouraged their critical and reflective thinking. The intermediary findings of the research implied that social/collaboration skills could be best revealed if students were encouraged to apply them in practice. The open-ended survey administered at the beginning of the experimental treatment showed students' rather narrow understanding of information literacy which was limited to IT or computer literacy. However, the comparative analysis of the mean scores of information literacy test administered two times revealed that the experimental group students mastered the knowledge on information literacy and could apply it in practice. The obtained data on students ESP learning outcomes indicated better performance and results for the experimental group students compared to the control group and proved statistical significance of a difference between the groups. Thus, in conclusion we state that the information literacy course integrated into ESP syllabus had a positive impact on students' attitudes towards technologically rich learning environment, their social interaction and contributed to evident progress in ESP.

\section{References}

ALA (1998). Progress Report on Information Literacy. American Library Association: Final Report http: / / www. infolit.org. documents/progress.htm

ANZIL (2004). Australian \& New Zealand Information Literacy Framework: Principles, Standards and Practice. Second edition. Adelaide.

Applefield, J.M. and Huber, R. (2001). Constructivism in theory and practice: toward a better understanding High School Journal, 84(2), 35-49.

Bawden, D. and Robinson, L. (2002). Promoting Literacy in a Digital Age: Approaches to Training for Information Literacy, 15(4). Learned Publishing, London City University.

Behrens, S. (1994). A conceptual analysis and historical overview of information literacy. College and Research Libraries, 55, 309-322.

Berglund, A. (2004). A framework to study learning in a complex learning environment. Research in Learning Technology, 12(1), 65-79.

Chang, V. and Fisher, D.L. (1998). New Learning Environment Instrument. http: / / education.curtin.edu.au/waier/forums/chang.html

Chang, V. and Fisher, D.L. (2003). The validation and application of a new learning environment instrument for online learning in higher education. In M.S. Khine and Fisher (Eds.), Technology-Rich Learning Environments: A Future Perspective. World Scientific Publishing Co, Singapore, 1-20.

Computer Literacy Standards for School Librarians (2002). Ministry of Education and Science of LR. http: / /www. emokykla.1t/en.php/documents / 672 
Report of the Committee by the Government of the Republic of Lithuania (2003). Development of Information Society in Lithuania. Year 2002. Vilnius (in Lithuanian).

Dougiamas, M. and Taylor, P. (2003). Moodle: using learning communities to create an open source course management system. In Proceedings of the EDMEDIA Conference, Honolulu, Hawaii. http: / / dougiamas.com/writing/edmedia2003/

Dougiamas, M. (1998). A Journey into Constructivism. http: / /dougiamas.com/writing/constructivism.html

Implementation of Education and Training 2010. Work Programme: Key competences for lifelong learning, A European Reference Framework (2004). European Commission Directorate - General for Education and Culture, p. 20.

http: / / europe.eu.inf/comm/education/policies/2010/doc/basicframe.pdf

Gedvilienè, G. and Vaičiūnienè, V. (2005). Information literacy competency as a premise for successful adult education in the civil society. In L. Jogi, E. Przybylska, M. Teresevičienè (Eds.), Adult Learning for the Civil Society, vol. 51. Institute for International Cooperation, Bonn-Kaunas-Warsaw, 69-82.

General Computer Literacy Standard (2004). Ministry of Education and Science of LR. http: / / www . emokykla.1t/en.php/documents / 672

Johnston, B. and Webber, Sh. (2000). Towards information literate graduate: rethinking the undergraduate curriculum in business studies. In K. Appleton, C. Macpherson and D. Orr (Eds.), Lifelong Learning Conference: Selected Papers. Yeppoon, Queensland, Australia, July 2000, 194-202.

Johnston, B. and Webber, Sh. (2003). Information literacy in higher education: a review and case study. Studies in Higher Education, 28(3).

Jones, Ch. (2004). Networks and learning: communities, practices and the metaphor of networks. Research in Learning Technology, 12(1).

Jucevičienè, P. and Tautkevičienè, G. (2002). Triangle of competences as one of the basic characteristics of the university library learning environment. In European Conference of Educational Research. Lisbon, September 2002, 1-9. http: / / www. leeds. ac.uk/educol / documents / 00002343 . htm

Jucevičienè, P. and Tautkevičienè, G. (2004). The library learning environment as a part of university educational environment. In European Conference of Educational Research. University of Crete, September 2004. http: / / www . leeds.ac.uk/educol/documents / 00002343 . htm

Limberg, L. (1997). Experiencing Information Seeking and Learning: A Study of the Interaction between Two Phenomena. Dissertation summary.

http: / /www.ped.gu.se/biorn/phgraph/civil/graphica/diss.su/limber.html

Lisbon Special European Council (2000). Towards a Europe of Innovation and Knowledge.

Parliament of the Republic of Lithuania (2002). Long Term Development Strategy of the State. Resolution No. IX-1187 November 12, 2002.

Loveless, A.M. (2002). Literature review in creativity. New Technologies and Learning. Report 4, p. 38 http: //www. nestafuturelab.org/research/reviews/cr09.htm 2005.04.16.

Marton, F. and Fai, P.M. (1999). Two faces of variation. Paper presented at 8th European Conference for Learning Instruction, August 24-28, 1999, Gőteborg, Sweden.

Strategy of ICT in Education (2000). Order No. 1279 Ministry of Education and Science of LR. Approved 2000.

Students' General Computer Literacy Standard (2001). Ministry of Education and Science of the Republic of Lithuania. http://www. emokykla.1t/en.php/documents / 672

Teachers' Computer Literacy Standard (2001). Ministry of Education and Science of the Republic of Lithuania. http: / / www . emokykla.1t/1t.php/documents / 672

Teresevičienè, M. and Gedvilienè, G. (2003). Learning in Groups and Personality Change. Vytautas Magnus University, Kaunas.

Vygotsky, L.S. (1978). Mind in Society. Harvard University Press, Cambridge, Massachusetts. 
V. Vaičiunienè is a doctor of social sciences, a lecturer of the Foreign Languages Department at Mykolas Romeris University, Vilnius. The author's major research interests are: information literacy, learning in higher education, adult learning, and innovative foreign language teaching methods. The author participates in projects related to innovative foreign language teaching. She is the winner of the European Label, 2002 for the "Interactive English Language Tool for Customs Officials". Currently she is involved in EU Structural Funds Project run at Mykolas Romeris University "Developing Lifelong Learning Access: Innovative Means and Methods in Teaching Foreign Languages at Mykolas Romeris University".

G. Gedvilienè is an assoc. professor at the Department of Education, vice-dean of the Faculty of Social Sciences, Vytautas Magnus University, Kaunas. The author's research interests focus on adult learning, cooperative methods in learning, group dynamics. She also participates in international projects within SOCRATES, GRUNDTVIG, ERASMUS, EFT, PHARE. She is the co-author of a monograph "Learning in Groups and Personality Change" and course book "Adult Learning". 


\title{
Studentu mokymosi patirtis taikant integruota informacinio raštingumo kursa virtualioje mokymosi aplinkoje
}

\author{
Vilhelmina VAIČIŪNIENĖ, Genutė GEDVILIENĖ
}

Straipsnyje analizuojama informacinio raštingumo ir specialybės užsienio kalbos gebejjimu plètra virtualioje mokymosi aplinkoje bei šios aplinkos poveikis studentu gebejjimu plètojimui, aptariant edukologinio eksperimento, atlikto MRU, rezultatus. Eksperimentinè situacija buvo operacionalizuota, pateikiant tyrejos parengtą inovatyvią programą „Informacinio raštingumo integravimas i specialybès anglu kalbos programą bakalauro pakopos studijose MRU“, patalpinta i „Moodle“ aplinką, turinčią tarpdisciplininio mokymo/si bruožų, kurioje specialybès anglu kalbos mokymas/sis buvo derinamas su informacinio raštingumo mokymu. Eksperimente dalyvavo bakalauro pakopos dieniniu studijų I kurso dvi studentu grupès: eksperimentinis poveikis buvo taikomas eksperimentinei grupei, o kontrolinė grupe buvo mokoma pagal MRU patvirtinta specialybès anglu kalbos programą. Fenomenografinis informacinio raštingumo sampratos tyrimas atskleidè, kad studentai informacinị raštingumą dažnai sieja tik su kompiuterio ar technologiju išmanymu. Tokia informacinio raštingumo samprata gali tapti rimtu trukdžiu skatinant gilumini studentu požiūrị ị mokymąsi ir siekiant studijų efektyvumo bei kokybès. Virtualios mokymosi aplinkos „Moodle“ vertinimo tyrimas atskleidè stiprią teigiamą tarpusavio sąveiką tarp informacinio raštingumo kompetenciju, kritinio mąstymo gebẻjimu plètojimo ir lanksčios Moodle aplinkos, kuri sudaro sąlygas studentams mokytis jiems tinkamu laiku, vysto gebejjimus būtinus ateities studijoms ir darbinei karjerai. Eksperimentinis poveikis turèjo įtakos studentu požiūriui ị socialinius ir bendradarbiavimo gebėjimus, kuris, pasibaigus eksperimentui, parodè studentu didesni polinkị i bendradarbiavimą ir norą dalintis žiniomis. Tyrimo rezultatai patvirtino eksperimentinio poveikio veiksmingumą specialybès anglu kalbai eksperimentinèje grupejje ir informacinio raštingumo žinioms. 